\title{
Leukopenia-Inducing Effect of a Combination of a New 5-Fluorouracil (5-FU)-Derived Drug, BOF-A2 (Emitefur), with Other 5-FU-Derived Drugs or BV-araU (Sorivudine) in Rats
}

\author{
Shun Miyauchi ${ }^{1}$, Takeshi Imaoka ${ }^{1}$, Tadashi Okada ${ }^{1}$, Masaaki Motoyama ${ }^{1}$, Teruhisa Kawaguchi ${ }^{2}$, \\ Hitoshi Akiyama ${ }^{2}$ and Masaaki Odomi ${ }^{2}$ \\ ${ }^{1}$ Fujii Memorial Research Institute, Otsuka Pharmaceutical Co., Ltd., 11-1, 1-chome, Karasaki, Ohtsu, Shiga 520-01, Japan \\ ${ }^{2}$ Tokushima Research Institute, Otsuka Pharmaceutical Co., Ltd., 463-10, Kawauchi, Tokushima 77I-01, Japan
}

Received July 28, 1995 Accepted November 10, 1995

\begin{abstract}
BOF-A2 (emitefur: 3-\{3-[6-benzoyloxy-3-cyano-2-pyridyloxycarbonyl]benzoyl\}-1-ethoxymethyl-5-fluorouracil), a novel 5-FU (5-fluorouracil)-derived drug, was co-administered with other conventional 5-FU-derived drugs or BV-araU [sorivudine: 1- $\beta$-D-arabinofuranosyl-(E)-5-(2-bromovinyluracil)] for 8 consecutive days to rats. BOF-A2 ( 6 or $8 \mathrm{mg} / \mathrm{kg}$, p.o.) co-administered with other 5 -FU-derived drugs elevated the plasma 5-FU concentration 3- to 23.3-fold and decreased the peripheral white blood cell (WBC). The percentage decreases of WBC by 5 -FU ( $4 \mathrm{mg} / \mathrm{kg}$, i.p.), UFT (16 mg/kg, p.o.), tegafur (FT; $16 \mathrm{mg} / \mathrm{kg}$, p.o.), carmofur (HCFU; $15 \mathrm{mg} / \mathrm{kg}$, p.o.), doxifluridine (5'-DFUR; $16 \mathrm{mg} / \mathrm{kg}, \mathrm{p} .0$. ) and flucytosine (200 $\mathrm{mg} / \mathrm{kg}, \mathrm{p.o}$.) were $25.7 \%, 31.9 \%, 70.3 \%, 32.0 \%, 58.6 \%$ and $30.0 \%$, respectively, compared with each drug alone. On the other hand, these phenomena did not occur with BV-araU. These findings can be attributed to the fact that the inhibitory activity of CNDP (3-cyano-2,6-dihydroxypyridine) for 5-FU degradation $\left(\mathrm{IC}_{50}: 6.3 \times 10^{-9} \mathrm{M}\right)$ is potent and 6000 times greater than that of $\mathrm{BVU}$ [(E)-5-(2-bromovinyl) uracil], another inhibitor of 5 -FU degradation.
\end{abstract}

Keywords: Emitefur (BOF-A2), 5-Fluorouracil-derived drug, Sorivudine (BV-araU), Leukopenia

Uracil and 5-substituted uracil derivatives accelerate the antitumor activity of 5-fluorouracil (5-FU)-derived drugs by inhibiting $5-\mathrm{FU}$ degradation (1-4). As shown in Fig. 1, CNDP (3-cyano-2,6-dihydroxypyridine) is a more potent inhibitor of 5-FU degradation than uracil (5). BOF-A2 (3-\{3-[6-benzoyloxy-3-cyano-2-pyridyloxycarbonyl]benzoyl \}-1-ethoxymethyl-5-fluorouracil), a novel 5-FU-derived antineoplastic drug, was developed by conjugating CNDP and EM-FU (1-ethoxymethyl-5fluorouracil), a $5-\mathrm{FU}$ precursor that steadily releases $5-\mathrm{FU}$ via liver microsomes (6).

Consequently, due to the persistence of 5-FU in the plasma or tumor tissue compared with other 5-FUderived drugs, BOF-A2 has potent antitumor activity against experimental tumors and human cancer xenografts $(7,8)$. Thus, BOF-A2 is used more than other 5-FU-derived drugs in lung cancer patients (9).

Cancer patients are rarely treated with one drug alone, and most anticancer drugs are co-administered with other agents such as antiviral drugs, hormones and/or steroids. A combination of the antiviral drug BV-araU [1- $\hat{\beta}-\mathrm{D}-$
arabinofuranosyl-(E)-5-(2-bromovinyluracil)] with 5-FUderived anticancer drugs causes severe leukopenia (10). This condition is also induced by a high 5 -FU dosage or a high plasma 5-FU concentration $(11-13)$. The BVU [(E)-5-(2-bromovinyl) uracil] metabolite of BV-araU elevates the 5 -FU concentration in the blood by inhibiting dihydropyrimidine dehydrogenase (DPDase) (14). This acute elevation in the 5-FU concentration suggests that catabolism inhibition by drug-interactions may increase adverse side effects in humans. Though it is unlikely that BOF-A2 will be combined with other 5-FU-derived anticancer drugs, this danger cannot be ignored.

We studied the effect of BOF-A2 in combination with other 5-FU-derived drugs and BV-araU on the 5-FU concentration in the blood and upon leukopenia in rats.

\section{MATERIALS AND METHODS}

\section{Animals}

Male Sprague-Dawley strain rats at the age of 6-8 weeks were purchased from Clea Japan, Inc. (Tokyo) for 


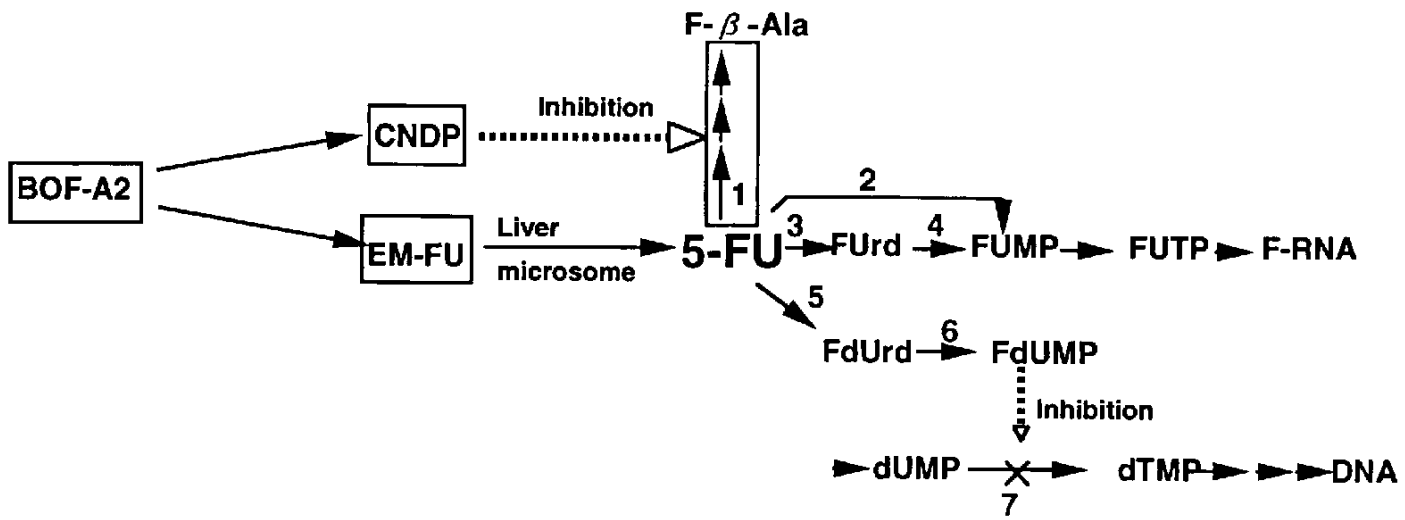

$\begin{array}{ll}1 & \text { Dihydropyrimidine dehydrogenase (DPDase) } \\ 2 & \text { Pyrimidine phosphoribosyl transferase } \\ 3 & \text { Uracil ribosyltransferase } \\ 4 & \text { Uridine kinase }\end{array}$

5 Uracil deoxyribosyltransferase

6 Thymidine kinase

7 Tymidylate synthase

BOF-A2: 3-\{3-[6-benzoyloxy-3-cyano-2-pyridyloxycarbonyl]benzoyl $\}$-1-ethoxymethyl-5-fluorouracil CNDP: 3-cyano-2,6-dihydroxypyridine F-RNA: fluorinated-ribonucleic acid EM-FU: 1-ethoxymethyl-5-fluorouracil FdUrd: 5-fluoro-2'-deoxyuridine 5-FU: 5-fluorouracil F- $\beta$-Ala: $\alpha$-fluoro- $\beta$-alanine FUrd: 5-fluorouridine FUMP: 5-fluorouridine 5'-monophosphate FUTP: 5-fluorouridine 5'-triphosphate FdUMP: 5-fluoro-2'-deoxyuridine 5'-monophosphate dUMP: 2'-deoxyuridine 5'-monophosphate dTMP: thymidine 5'-monophosphate DNA: deoxyribonucleic acid

Fig. 1. Proposed metabolic pathway of BOF-A2.

repeated administration and from Charles River Japan, Inc. (Kanagawa) for single administration. The rats were housed in a temperature $\left(24 \pm 2{ }^{\circ} \mathrm{C}\right)$ - and humidity $(60 \pm 10 \%)$-controlled room. The experiments were begun after a preliminary housing period of one week.

\section{Drugs}

BOF-A2 was synthesized at the Second Factory of Otsuka Pharmaceutical Co., Ltd. (Tokushima). The following were obtained from commercial sources: FT and UFT (Taiho Pharmaceutical Co., Ltd., Tokyo), 5-FU (Daikin Kogyo Co., Ltd., Tokyo), 5'-DFUR and flucytosine (Nippon Roche, Tokyo) and HCFU (Yamanouchi Pharmaceutical Co., Ltd., Tokyo). BV-araU was provided by Yamasa Shoyu Co., Ltd., Chiba. The method of BOF-A2 synthesis is described elsewhere (6), and the structures of all drugs applied are shown in Fig. 2. All other chemicals used were of analytical grade. All drugs except for 5-FU were suspended in 1\% HPMC (hydroxypropyl methyl cellulose) by stirring for 10 to $30 \mathrm{~min}$. 5-FU was dissolved in saline for repeated administration or in $1 \%$ HPMC for single administration.

Effect of repeated co-administration of BOF-A2 with other 5-FU-derived drugs (5-FU, UFT, FT, 5-DFUR, $H C F U$ and fucytosine) on white blood cell (WBC) and plasma 5-FU concentration
The doses of the drugs given in combination were set at the respective minimum doses of $4 \mathrm{mg} / \mathrm{kg}$, i.p. for $5-\mathrm{FU}$; $6 \mathrm{mg} / \mathrm{kg}$, p.o. for BOF-A2 and UFT; $15 \mathrm{mg} / \mathrm{kg}$, p.o. for HCFU; and $16 \mathrm{mg} / \mathrm{kg}$, p.o. for FT and 5'-DFUR. Each 5-FU-derived drug was administered once daily for 8 days alone or in combination with BOF-A2 to 7 normal rats per group. The rats were weighed before each administration. Five milliliters of heparinized blood per rat was collected $1 \mathrm{hr}$ after the final administration, and peripheral WBC and plasma 5-FU concentrations were measured. For the 8-day consecutive combination treatment of BOF-A2 $(8 \mathrm{mg} / \mathrm{kg}$, p.o.) and flucytosine $(200$ $\mathrm{mg} / \mathrm{kg}$, p.o.), $5 \mathrm{ml}$ of blood per rat was collected $2 \mathrm{hr}$ after the final administration.

Effect of single co-administration of BOF-A2 with 5-FU or UFT

The doses were $20 \mathrm{mg} / \mathrm{kg}$, p.o. for BOF-A2 and UFT and $4.7 \mathrm{mg} / \mathrm{kg}$, p.o. for $5-\mathrm{FU}$ (equimolar to $20 \mathrm{mg} / \mathrm{kg}$ of BOF-A2). The drugs alone or in combination with BOFA2 were orally administered once to 3 rats at each point described below. Five milliliters of heparinized blood per rat was collected at $0.17,0.33,0.5,0.75,1,2,4,6,8,12$ and $24 \mathrm{hr}$ after the combination of BOF-A2 and 5-FU, and at $0.5,1,2,4,6,8$ and $12 \mathrm{hr}$ after the combination of BOF-A2 and UFT. The AUC (area under the curve, $\mathrm{ng} \cdot \mathrm{hr} / \mathrm{ml}$ ) for the plasma 5 -FU concentration was deter- 


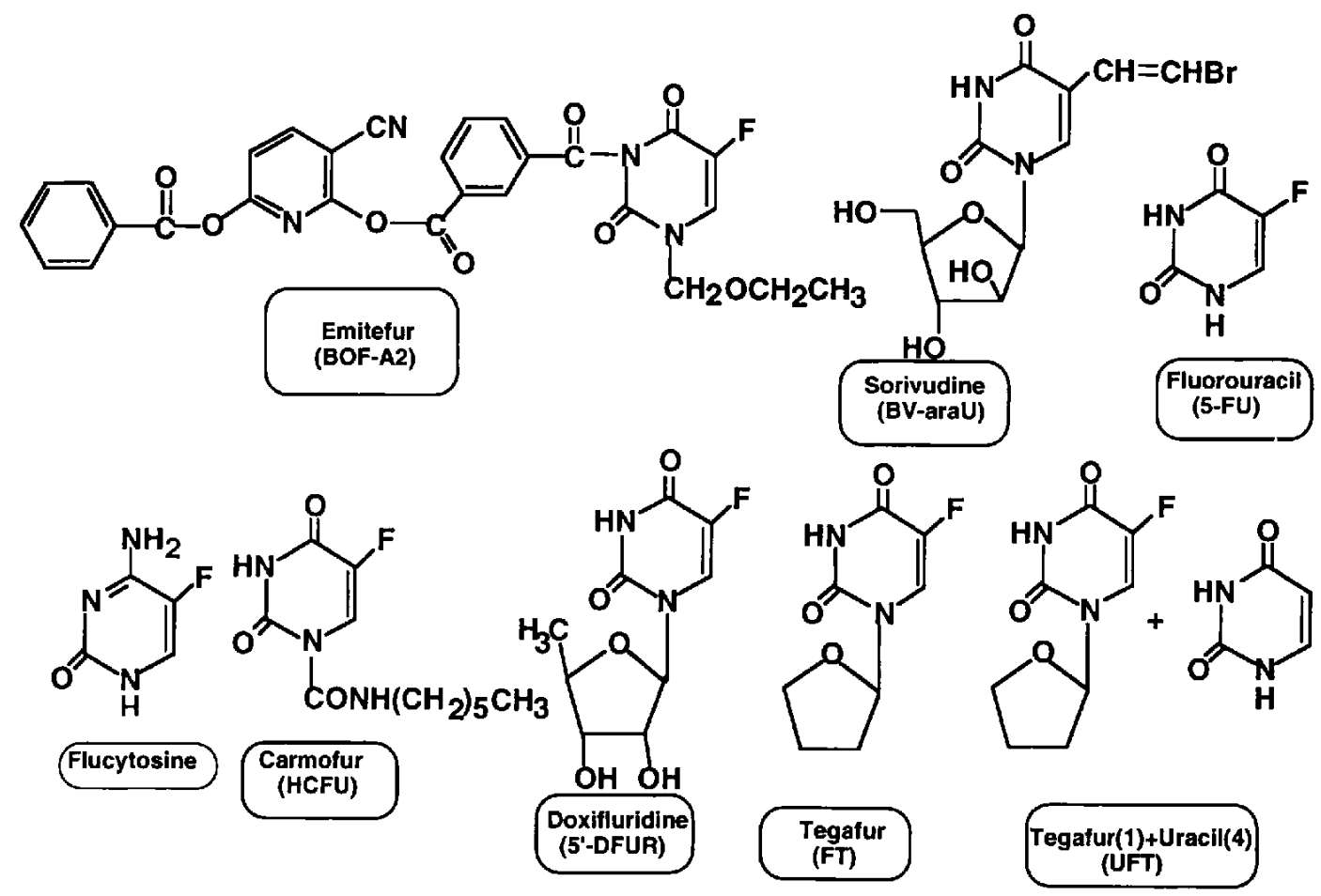

Fig. 2. Structural formula of test compounds.

mined by means of the trapezoidal rule.

Effect of repeated co-administration of $B V$-araU with $B O F-A 2$ or UFT on WBC and plasma 5-FU concentration

The doses of oral BV-araU used in combination were 20 and $100 \mathrm{mg} / \mathrm{kg}$, and those of oral BOF-A2 and UFT were 10,20 and $40 \mathrm{mg} / \mathrm{kg}$. BV-araU was given once daily for 8 days alone or in combination with BOF-A2 or UFT to 7 rats. The rats were weighed before each administration. Five milliliters of heparinized blood per rat was collected $1 \mathrm{hr}$ after the final administration, and peripheral WBC and plasma 5-FU concentration were measured.

Effect of single co-administration of $B V$-ara $U$ with $B O F-$ A2 or 5-FU

The dose of oral BV-araU was set at $20 \mathrm{mg} / \mathrm{kg}$ and that of oral BOF-A2 and 5-FU combined with BV-araU at 20 $\mathrm{mg} / \mathrm{kg}$ and $4.7 \mathrm{mg} / \mathrm{kg}$ (equimolar to $20 \mathrm{mg} / \mathrm{kg}$ of BOFA2), respectively. The drugs were orally administered once to 3 rats at each point described below. Five milliliters of heparinized blood per rat was collected at 0.17 , $0.33,0.5,0.75,1,2,4,6$ and $8 \mathrm{hr}$ after the co-administration of BV-araU and 5-FU, and at 0.5, 1, 2, 4, 6, 8, 12 and $24 \mathrm{hr}$ after the co-administration of BV-araU and BOF-A2. Plasma 5-FU, EM-FU and CNDP concentrations were measured by HPLC (high performance liquid chromatography), and the AUC for each metabolite was determined by means of the trapezoidal rule.

Determination of plasma 5-FU concentration by GC-MS

The plasma 5-FU concentration was measured 1 or $2 \mathrm{hr}$ after the final administration of BOF-A2 and the other 5FU-derived drugs by a partially modified version of the GC-MS (gas chromatography-mass spectrometer) procedure reported by Kubo et al. (15). Five milliliters of heparinized blood collected through the inferior vena cava was centrifuged at 3,000 r.p.m. for $10 \mathrm{~min}$. The supernatant was kept at $-20^{\circ} \mathrm{C}$ until the plasma 5 -FU concentration was determined. Distilled water $(2 \mathrm{ml})$ containing $0.1 \mu \mathrm{g}$ of internal standard $\left(1,3-\mathrm{bis}-{ }^{15} \mathrm{~N}-5-\mathrm{FU}\right)$, $50 \mu \mathrm{l}$ of $5 \mathrm{~N}$ hydrochloric acid and $40 \mathrm{ml}$ of chloroform methanol (50:1) was added to $250 \mu \mathrm{l}$ of plasma and shaken. To the aqueous phase, $40 \mathrm{ml}$ of ethyl acetate was added to extract 5-FU. The organic phase was evaporated to dryness under a stream of $\mathrm{N}_{2}$ gas. Silylation of the 5FU was performed as follows: A mixture of $1 \mathrm{ml}$ of $\mathrm{N}, \mathrm{O}$ bis-(trimethylsilyl) trifluoroacetamide (BSTFA), $1 \mathrm{ml}$ of pyridine and $2 \mathrm{ml}$ of toluene was added to the test tube and heated for $20 \mathrm{~min}$ at $80^{\circ} \mathrm{C}$. The ion peak $(\mathrm{M} / \mathrm{Z}=274.4,276.4)$ corresponding to the molecular ion peak of silylated $5-\mathrm{FU}$ or silylated internal standard was monitored by GC-MS. 
Determination of plasma 5-FU EM-FU and CNDP by HPLC

The plasma 5-FU concentrations after consecutive co-administration of BOF-A2 with BV-araU and after a single administration of BOF-A2 with 5-FU or UFT were determined by HPLC. Five milliliters of heparinized blood collected through the inferior vena cava of each rat was quickly centrifuged for plasma preparation.

We extracted 5-FU as follows: An internal standard comprised of 5-bromouracil $(0.01 \mathrm{ml}), 1 \mathrm{ml}$ of saturated ammonium sulfate and $5 \mathrm{ml}$ of $\mathrm{CHCl}_{3}$ was added to $1 \mathrm{ml}$ of plasma sample and shaken. To extract the 5-FU, ethyl acetate $(3 \mathrm{ml})$ was added to the aqueous phase; this extraction by ethyl acetate was repeated once more. The organic phase was evaporated to dryness under a stream of air and then dissolved in $100 \mu \mathrm{l}$ of water for HPLC. The conditions for HPLC were as follows: mobile phase of $0.1 \mathrm{~N}$ acetic acid, 280-nm UV detection wave, YMC A-303 reverse-phase column $(4.6 \times 150 \mathrm{~mm})$ (YMC Co., Ltd., Kyoto).

CNDP was extracted as follows: aliquots of an internal standard comprised of 5-carbamoyl-3-fluoro-2,6-dihydroxypyridine (synthesized by the Fujii Memorial Research Institute, Otsuka Pharmaceutical Co., Ltd., Ohtsu) and $400 \mu \mathrm{l}$ of $\mathrm{CH}_{3} \mathrm{CN}$ were added to $100 \mu \mathrm{l}$ of the plasma sample, and then the mixture was separated by centrifugation. The supernatant was evaporated to dryness under a stream of air and then dissolved in $100 \mu \mathrm{l}$ of
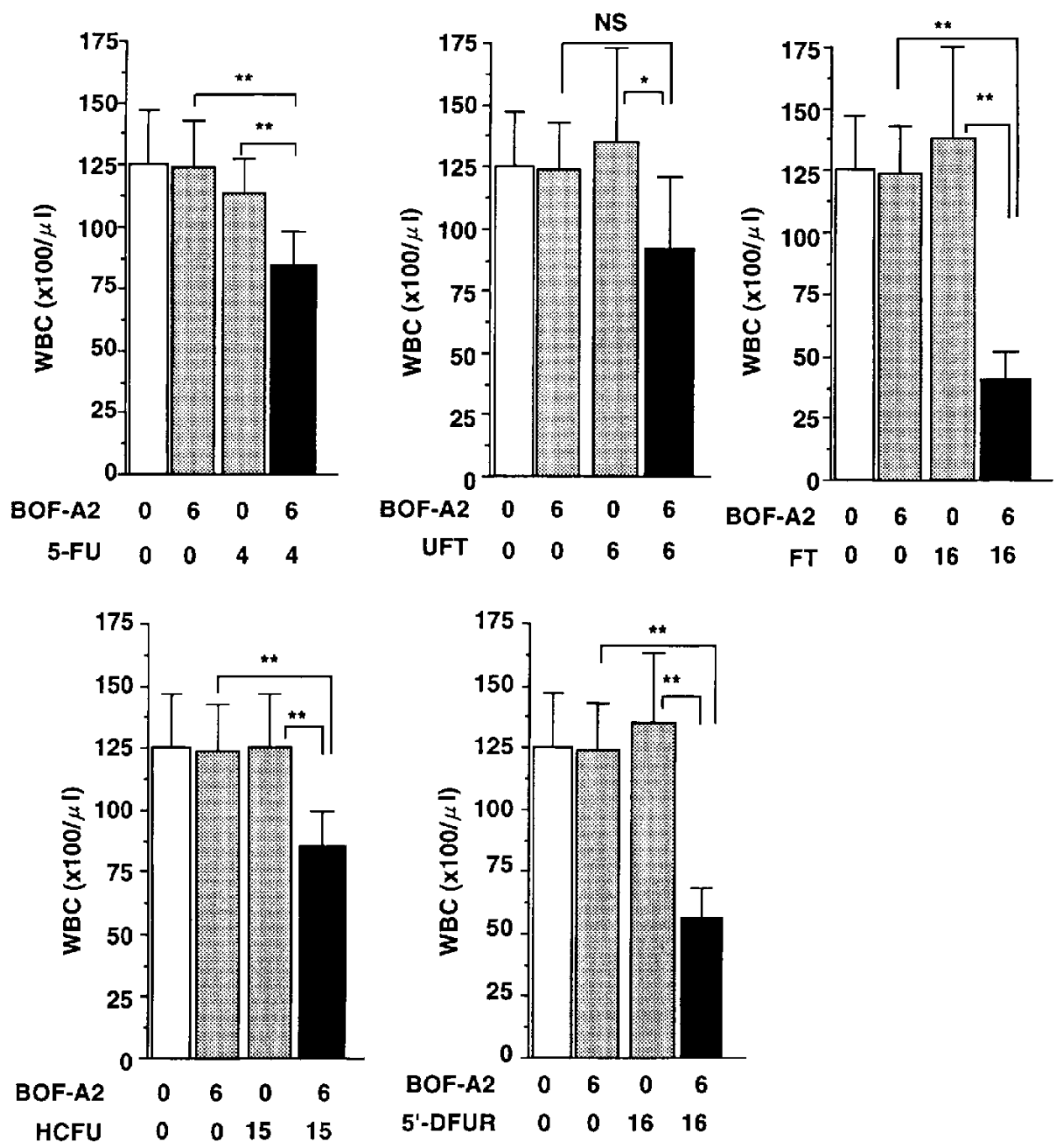

Fig. 3. Effect of combining 5-FU-derived drugs with BOF-A2 on the white blood cell (WBC). BOF-A2 (6 mg/kg, p.o.) combined with other 5-FU-derived drugs (5-FU, $4 \mathrm{mg} / \mathrm{kg}$, i.p.; UFT, $6 \mathrm{mg} / \mathrm{kg}$, p.o.; FT, $16 \mathrm{mg} / \mathrm{kg}$, p.o.; HCFU, $15 \mathrm{mg} / \mathrm{kg}$, p.o.; 5 -DFUR, $16 \mathrm{mg} / \mathrm{kg}$, p.o.) was administered to SD strain rats once daily for 8 consecutive days, and peripheral WBC was counted $1 \mathrm{hr}$ after the final dose. Values are expressed as means \pm S.D. of 7 rats in each group. NS: Not significant. ${ }^{*} \mathbf{P}<0.05$, ${ }^{* *} \mathbf{P}<0.01$ (significant difference between combination and non-combination groups by Dunnett's test). 
the HPLC mobile phase. The conditions for HPLC were as follows: mobile phase of $\mathrm{CH}_{3} \mathrm{CN}-0.1 \mathrm{M}$ acetate buffer (1:99) (pH 5.0), 330-nm (Ex) and 380-nm (Em) detection wave, YMC A-302 reverse-phase column $(4.6 \times 150 \mathrm{~mm})(\mathrm{YMC} \mathrm{Co}$., Ltd.).

EM-FU was extracted as follows: aliquots of an internal standard comprised of 1-ethoxymethylthymine (synthesized by the Fujii Memorial Research Institute, Otsuka Pharmaceutical Co., Ltd.) and $1 \mathrm{ml}$ of saturated ammonium sulfate were added to $1 \mathrm{ml}$ of the plasma sample; and this mixture was shaken with $5 \mathrm{ml}$ of $\mathrm{CHCl}_{3}$. The organic phase was evaporated to dryness under a stream of air and then dissolved in $100 \mu \mathrm{l}$ of $30 \%$ methanol. The conditions for HPLC were as follows: mobile phase of
$\mathrm{CH}_{3} \mathrm{CN}$ - acetic acid $-\mathrm{H}_{2} \mathrm{O}(10: 1: 89), 280-\mathrm{nm}$ UV detection wave, YMC A-302 reverse-phase column $(4.6 \times 150$ $\mathrm{mm}$ ) (YMC Co., Ltd.). The extraction of BVU, which is a metabolite of BV-araU, and the HPLC analysis were performed under the conditions used for EM-FU.

\section{Determination of $W B C$}

The peripheral WBC in blood collected through the inferior vena cava using a heparinized syringe was counted in an automatic microcell counter equipped with electrical resistor (Sysmex F-800; Toa Medical Electronic Co., Ltd., Tokyo).
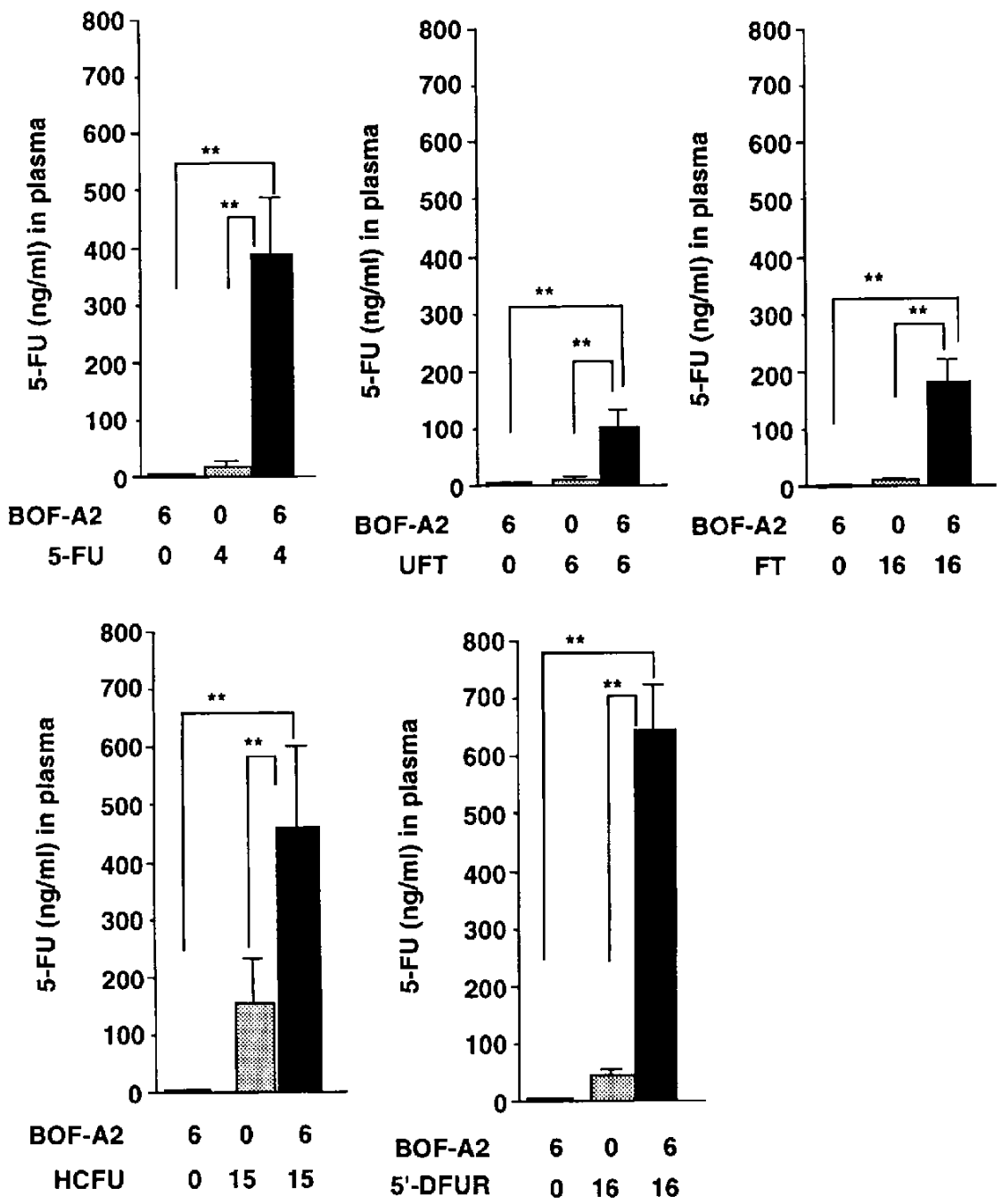

Fig. 4. Effect of combining 5-FU-derived drugs with BOF-A2 on the plasma 5-FU concentration. BOF-A2 (6 mg/kg, p.o.) combined with other 5-FU-derived drugs (5-FU, $4 \mathrm{mg} / \mathrm{kg}$, i.p.; UFT, $6 \mathrm{mg} / \mathrm{kg}$, p.o.; FT, $16 \mathrm{mg} / \mathrm{kg}$, p.o.; HCFU, $15 \mathrm{mg} / \mathrm{kg}$ p.o., 5 -DFUR, $16 \mathrm{mg} / \mathrm{kg}$, p.o.) was administered to SD strain rats once daily for 8 consecutive days, and plasma was collected $1 \mathrm{hr}$ after the final dose to determine the plasma 5-FU concentration. Values are expressed as means \pm S.D. of 7 rats in each group. ${ }^{* *} \mathrm{P}<0.01$ (significant difference between combination and non-combination groups by Dunnett's test). 

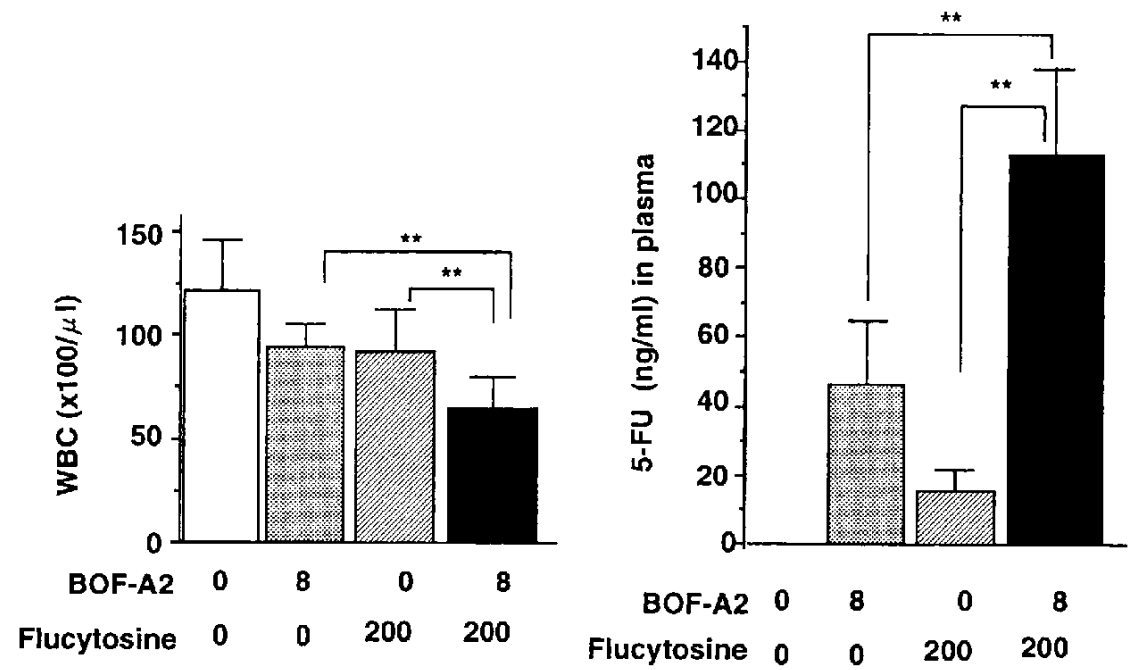

Fig. 5. Effect of combining flucytosine with BOF-A2 on the white blood cell (WBC) and the plasma 5-FU concentration. BOF-A2 ( $8 \mathrm{mg} / \mathrm{kg}$, p.o.) combined with flucytosine $(200 \mathrm{mg} / \mathrm{kg}, \mathrm{p} .0$.) was administered to SD strain rats once daily for 8 consecutive days, and blood and plasma were collected $2 \mathrm{hr}$ after the final dose to determine the peripheral WBC count and plasma 5-FU concentration. Values are expressed as means \pm S.D. of 7 rats in each group. ${ }^{* *} \mathrm{P}<0.01$ (significant difference between combination and non-combination groups by Dunnett's test).

\section{Inhibitory activity of each inhibitor on 5-FU degradation}

The inhibitory activity of each inhibitor (CNDP, uracil, BVU and BV-araU) on 5-FU degradation was determined in normal rat liver tissue homogenates. The liver of SD-rats (6-weeks-old) was excised under anesthesia and immediately homogenized $(20 \% \mathrm{~W} / \mathrm{V})$ in $0.25 \mathrm{M}$ sucrose containing $0.5 \mathrm{mM}$ EDTA and $5 \mathrm{mM} \beta$-mercaptoethanol. The homogenate was centrifuged for $60 \mathrm{~min}$ at $10,5000 \times g$, and the supernatant was dialyzed overnight

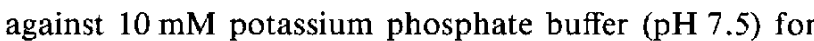
use as the crude enzyme. The reaction mixture containing the crude enzyme $(0.05 \%$ as liver weight), $45 \mathrm{mM}$ potassium phosphate buffer ( $\mathrm{pH} 7.5$ ), $50 \mathrm{mM}$ nicotinamide, 5
mM ATP, $25 \mathrm{mM} \mathrm{NaF}, 1 \mathrm{mM}$ NADPH, $10 \mu \mathrm{M}\left[^{3} \mathrm{H}\right] 5-\mathrm{FU}$ $(1.02 \mu \mathrm{Ci} / \mathrm{ml})$ and serial concentrations of each inhibitor was incubated for $30 \mathrm{~min}$ at $37^{\circ} \mathrm{C}$. The radioactivity was measured as described before (16).

\section{Statistical analyses}

The peripheral WBC count and plasma 5-FU concentration after consecutive administrations are expressed as means \pm S.D. Statistical analysis between combination groups was performed by dispersed analysis followed by Dunnett's test or Student's $t$-test. The P value of statistically significant differences was set at $\mathrm{P}<0.05$.

Table 1. Pharmacokinetic parameters of 5-FU in plasma after a single oral co-administration of BOF-A2 with other 5-FU-derived drugs

\begin{tabular}{lccccr}
\hline Drug & $\begin{array}{c}\text { Dose } \\
(\mathrm{mg} / \mathrm{kg})\end{array}$ & $\begin{array}{c}\text { Admin. } \\
\text { route }\end{array}$ & $\begin{array}{l}\mathrm{T}_{\max } \\
(\mathrm{hr})\end{array}$ & $\begin{array}{c}\mathrm{C}_{\max } \\
(\mathrm{ng} / \mathrm{ml})\end{array}$ & $\begin{array}{c}\mathrm{AUC}_{(-12 \mathrm{hr}} \\
(\mathrm{ng} \cdot \mathrm{hr} / \mathrm{ml})\end{array}$ \\
\hline BOF-A2 & 20 & p.o. & 8 & 335 & 2712 \\
5-FU & 4.7 & p.o. & 0.17 & 595 & 114 \\
UFT & 20 & p.o. & 1 & 849 & 1747 \\
BOF-A2 + 5-FU & $20+4.7$ & p.o. + p.o. & 0.33 & 3463 & 6403 \\
BOF-A2 + UFT & $20+20$ & p.o. + p.o. & 4 & 2143 & 14836 \\
BOF-A2 + BV-araU & $20+20$ & p.o. + p.o. & 6 & 377 & 2147 \\
5-FU + BV-araU & $4.7+20$ & p.o. + p.o. & 0.17 & 923 & 197 \\
\hline
\end{tabular}

BOF-A2 $(20 \mathrm{mg} / \mathrm{kg})$, UFT $(20 \mathrm{mg} / \mathrm{kg}), 5-\mathrm{FU}(4.7 \mathrm{mg} / \mathrm{kg})$ and BV-araU $(20 \mathrm{mg} / \mathrm{kg})$ were orally coadministered once to SD-strain rats, and the plasma 5-FU concentrations were measured by HPLC as described in Materials and Methods. Values are expressed as means of 3 rats in each group. 


\section{RESULTS}

Effect of repeated co-administration of $B O F-A 2$ with 5$F U$-derived drugs on $W B C$ and the plasma 5-FU concentration

As shown in Fig. 3, the peripheral WBC was significantly decreased by BOF-A2 combined with 5-FU, UFT, FT, HCFU and 5 -DFUR to levels of $25.7 \%$ $(\mathrm{P}<0.01), 31.9 \%, 70.3 \%(\mathrm{P}<0.01), 32.0 \%(\mathrm{P}<0.01)$ and $56.8 \%(\mathrm{P}<0.01)$, respectively, compared with each drug alone. As shown in Fig. 4, the plasma 5-FU concen- tration after combination of BOF-A2 with the other 5FU-derived drugs was remarkably elevated to 3-23.3 times that with each 5-FU-derived drug alone.

Effect of repeated co-administration of $B O F-A 2$ with flucytosine on $W B C$ and the plasma 5-FU concentration

As shown in Fig. 5, the combination of BOF-A2 and flucytosine significantly decreased the peripheral WBC by $31.0 \%(\mathrm{P}<0.01)$ and $30.0 \%(\mathrm{P}<0.01)$, respectively, compared with BOF-A2 and flucytosine alone. The combination of these drugs markedly increased the plasma 5-
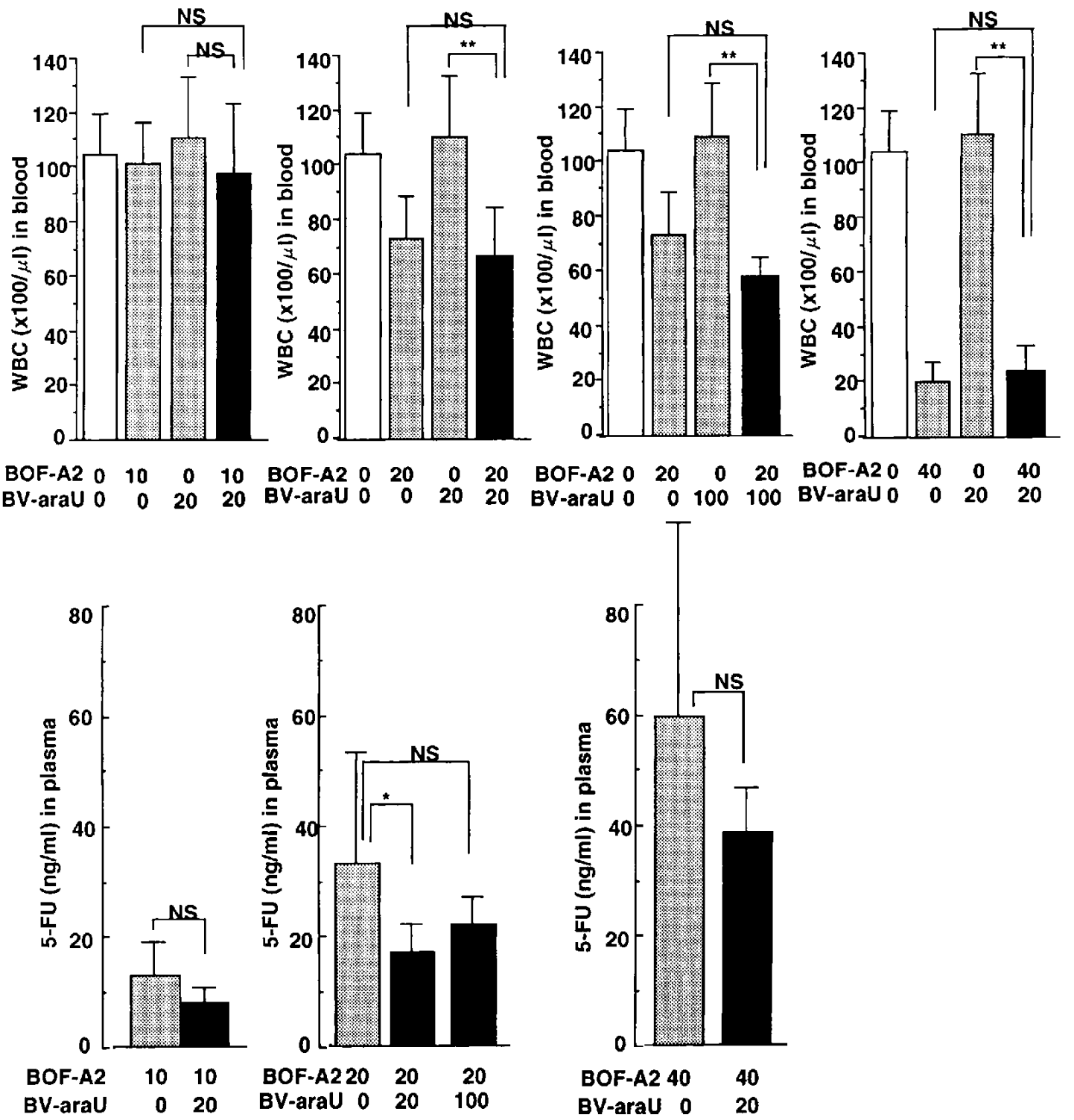

Fig. 6. Effect of BV-araU with BOF-A2 on the white blood cell (WBC) and the plasma 5-FU concentration. BOF-A2 (10, 20, $40 \mathrm{mg} / \mathrm{kg}$, p.o.) combined with BV-araU $(20,100 \mathrm{mg} / \mathrm{kg}$, p.o.) was administered to SD strain rats once daily for 8 consecutive days, and peripheral WBC and plasma 5-FU were measured after the final dose. Values are expressed as means \pm S.D. of 7 rats in each group. NS: not significant. ${ }^{*} \mathrm{P}<0.05,{ }^{* *} \mathrm{P}<0.01$ (significant difference between combination and non-combination groups by Dunnett's test or the $t$-test). 
FU concentration 7.3 times compared with flucytosine alone.

Effect of single co-administration of BOF-A2 with 5-FU or UFT

As shown in Table 1, at $3463 \mathrm{ng} / \mathrm{ml}$, the $\mathrm{C}_{\max }$ after the combined administration of BOF-A2 $(20 \mathrm{mg} / \mathrm{kg})$ with 5 $\mathrm{FU}(4.7 \mathrm{mg} / \mathrm{kg})$ was 5.8 times that after 5 -FU alone (595 $\mathrm{ng} / \mathrm{ml})$. The $\mathrm{AUC}_{0-12 \mathrm{hr}}$ of $6403 \mathrm{ng} \cdot \mathrm{hr} / \mathrm{ml}$ after combined administration was 2.3 times the sum $(2826 \mathrm{ng} \cdot \mathrm{hr} / \mathrm{ml})$ of the $\mathrm{AUC}_{0-12 \mathrm{hr}}$ of each drug alone.

On the other hand, at $2143 \mathrm{ng} / \mathrm{ml}$, the $\mathrm{C}_{\max }$ after combination of BOF-A2 $(20 \mathrm{mg} / \mathrm{kg})$ with UFT $(20 \mathrm{mg} / \mathrm{kg})$ was 2.5 -fold higher than that after UFT alone (849 $\mathrm{ng} / \mathrm{ml}$ ). The $\mathrm{AUC}_{0-12 \mathrm{hr}}$ of $14836 \mathrm{ng} \cdot \mathrm{hr} / \mathrm{ml}$ after combined administration was 3.3 times the sum (4459 $\mathrm{ng} \cdot \mathrm{hr} / \mathrm{ml}$ ) of the $\mathrm{AUC}_{0-12 \mathrm{hr}}$ of each drug alone.

Effect of repeated co-administration of $B V$-araU with $B O F-A 2$ or UFT on WBC and plasma 5-FU concentration

$\mathrm{BV}$-araU at doses of 20 or $100 \mathrm{mg} / \mathrm{kg}$ was co-administered once daily for 8 days with BOF-A2 or UFT at doses of 10,20 or $40 \mathrm{mg} / \mathrm{kg}$. As shown in Figs. 6 and 7 , the peripheral $\mathrm{WBC}$ and plasma 5-FU concentration were measured $1 \mathrm{hr}$ after the final co-administration.
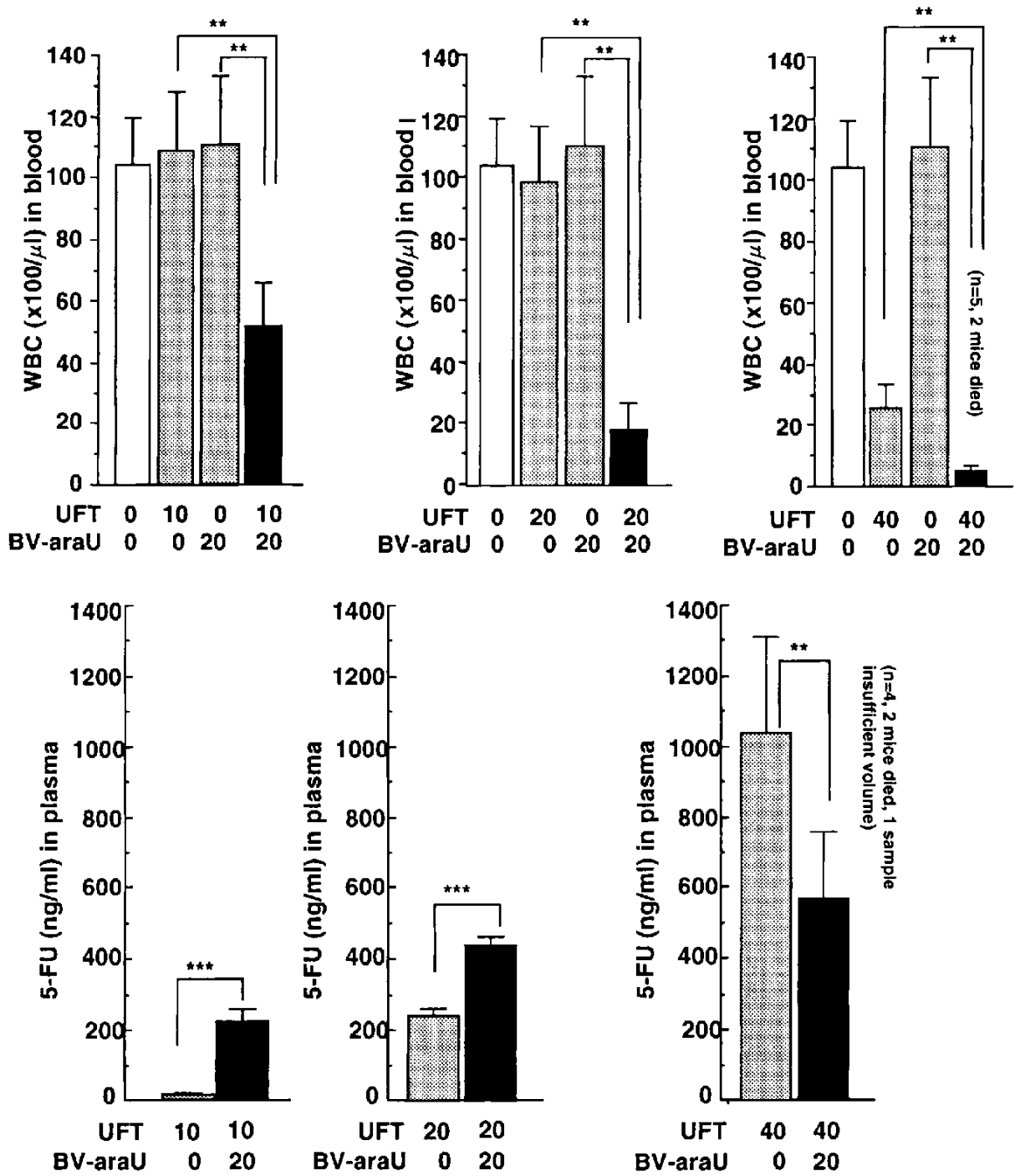

Fig. 7. Effect of BV-araU with UFT on the white blood cell (WBC) and the plasma 5-FU concentration. UFT (10, 20, 40 $\mathrm{mg} / \mathrm{kg}$, p.o.) combined with BV-araU $(20 \mathrm{mg} / \mathrm{kg}, \mathrm{p}$. .o.) was administered to SD strain rats once daily for 8 consecutive days, and peripheral $\mathrm{WBC}$ and plasma $5-\mathrm{FU}$ were measured $1 \mathrm{hr}$ after the final dosing. Values are expressed as means \pm S.D. of 7 rats in each group. ${ }^{* *} \mathrm{P}<0.01,{ }^{* * *} \mathrm{P}<0.001$ (significant difference bet ween combination and non-combination groups by Dunnett's test or the $t$-test). 


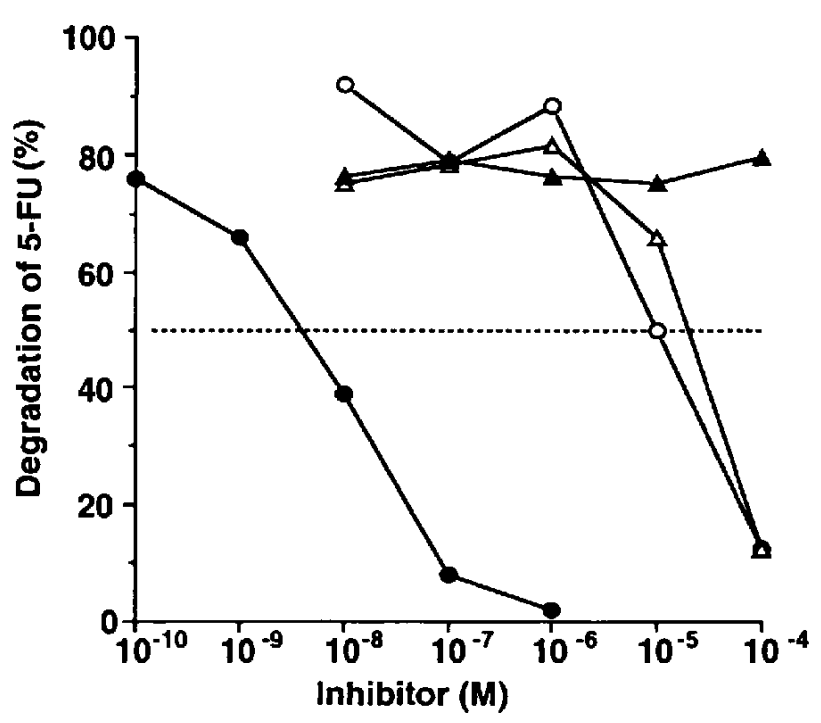

Fig. 8. Inhibitory effect of CNDP (O), uracil $(\bigcirc)$, BVU $(\triangle)$ and BV-araU (A) on 5-FU degradation in rat liver. The metabolites (F-i-Ala and FUPA) of 5-FU were measured by thin-layer chromatography after incubation for $30 \mathrm{~min}$ at $37^{\circ} \mathrm{C}$ with each inhibitor using $0.5 \%$ rat liver homogenate.

Diarrhea occurred on day 4 and two rats died on the final day of the combined administration of UFT ( 40 $\mathrm{mg} / \mathrm{kg})$ and $\mathrm{BV}$-araU $(20 \mathrm{mg} / \mathrm{kg})$, but not after the combined BOF-A2 with $\mathrm{BV}$-araU.

The co-administration of BOF-A2 (10,20 or $40 \mathrm{mg} / \mathrm{kg}$ ) with $\mathrm{BV}$-araU $(20$ or $100 \mathrm{mg} / \mathrm{kg}$ ) did not enhance the decrease in peripheral WBC at any dose tested. However, the peripheral WBC after co-administration of UFT at 10,20 or $40 \mathrm{mg} / \mathrm{kg}$ with BV-araU $(20 \mathrm{mg} / \mathrm{kg})$ decreased by $52.3 \% \quad(\mathrm{P}<0.01), \quad 81.8 \% \quad(\mathrm{P}<0.01)$ and $80.8 \%$ $(\mathrm{P}<0.01)$ respectively, compared with that after UFT alone.

The plasma 5-FU concentration was not elevated after the co-administration of BOF-A2 $(20 \mathrm{mg} / \mathrm{kg})$ with BVaraU at $100 \mathrm{mg} / \mathrm{kg}$ and conversely declined after the coadministration of BOF-A2 $(20 \mathrm{mg} / \mathrm{kg})$ with $\mathrm{BV}$-araU at $20 \mathrm{mg} / \mathrm{kg}$. However, co-administration of UFT with BVaraU $(20 \mathrm{mg} / \mathrm{kg})$ significantly elevated the plasma 5 -FU concentration to $226 \mathrm{ng} / \mathrm{ml}(\mathrm{P}<0.01)$ for UFT at 10 $\mathrm{mg} / \mathrm{kg}$ and to $434 \mathrm{ng} / \mathrm{ml}(\mathrm{P}<0.01)$ for UFT at $20 \mathrm{mg} / \mathrm{kg}$ compared with UFT alone $(15 \mathrm{ng} / \mathrm{ml}$ at $10 \mathrm{mg} / \mathrm{kg}$ and $241 \mathrm{ng} / \mathrm{ml}$ at $20 \mathrm{mg} / \mathrm{kg}$ ). Co-administration of a high dose $(40 \mathrm{mg} / \mathrm{kg})$ of UFT with BV-araU $(20 \mathrm{mg} / \mathrm{kg})$ did not elevate the plasma 5-FU concentration compared with UFT alone.

Effect of single co-administration of $B V$-araU with $B O F$ A2 or 5-FU

Table 1 shows the pharmacokinetic parameters when BV-araU $(20 \mathrm{mg} / \mathrm{kg})$ was administered $1 \mathrm{hr}$ before BOF-
A2 $(20 \mathrm{mg} / \mathrm{kg})$ or $5-\mathrm{FU}(4.7 \mathrm{mg} / \mathrm{kg})$. The $C_{\max }$ and $\mathrm{AUC}_{0-12 \mathrm{hr}}$ of 5-FU after co-administration of BOF-A2 with BV-araU were $377 \mathrm{ng} / \mathrm{ml}$ and $2147 \mathrm{ng} \cdot \mathrm{hr} / \mathrm{ml}$, respectively. These were 1.1 and 0.8 times the respective values after BOF-A2 alone, indicating that the plasma 5FU concentration was not elevated by co-administering BV-araU with BOF-A2. The $\mathrm{C}_{\max }$ and $\mathrm{AUC}_{0-24 \mathrm{hr}}$ of EMFU were unchanged. The $\mathrm{C}_{\max }$ of CNDP was $1198 \mathrm{ng} / \mathrm{ml}$ at $4 \mathrm{hr}$. The $\mathrm{C}_{\max }$ of BVU, a metabolite of BV-araU, was $248 \mathrm{ng} / \mathrm{ml}$ at $8 \mathrm{hr}$, and BVU persisted for as long as CNDP, although at a lower concentration. However, the $\mathrm{C}_{\max }$ and $\mathrm{AUC}_{0-12 \mathrm{hr}}$ of the plasma 5-FU after co-administration of $5-\mathrm{FU}$ with BV-araU were $923 \mathrm{ng} / \mathrm{ml}$ and $197 \mathrm{ng} \cdot \mathrm{hr} / \mathrm{ml}$, respectively, which were 1.6 and 1.7 times the respective values obtained after the administration of 5-FU alone.

Inhibitory activity of $C N D P$, uracil, $B V U$ and $B V$-araU on 5-FU degradation

As shown in Fig. 8, The $\mathrm{IC}_{50}$ values of CNDP, uracil, BVU and BV-araU on 5-FU degradation were $6.3 \times 10^{9}$, $6.4 \times 10^{-6}, 3.7 \times 10^{5} \mathrm{M}$ and over $10^{-4} \mathrm{M}$, respectively. CNDP was potently inhibitory, whereas the inhibitory activity of BVU was one-sixth that of uracil, and BVaraU itself was not inhibitory even at $10^{-4} \mathrm{M}$.

\section{DISCUSSION}

BOF-A2, which is a new 5-FU-derived antineoplsatic drug, rapidly releases EM-FU, a 5-FU precursor, and CNDP, a potent inhibitor of 5-FU degradation, after oral administration. EM-FU is further metabolized to 5-FU via liver microsomes. CNDP is simultaneously distributed in the body and potently inhibits DPDase, an enzyme found in normal liver and human lung cancer tissues that catalyze 5-FU degradation. As a result, BOF-A2 shows a potent antitumor activity $(5,9,16,17)$.

Because BOF-A2 contains CNDP, a potent inhibitor of the catabolic degradation of 5-FU, we considered that its co-administration with other 5-FU-derived antineoplastic drugs could invoke severe side effects.

We studied the effects of the co-administration of BOF-A2 with the other 5-FU-derived antineoplastic drugs, 5-FU, UFT, FT, HCFU and 5'-DFUR, and the 5FU-derived antifungal drug flucytosine on the plasma 5FU concentration and number of peripheral WBC in rats.

When BOF-A2 and other 5-FU-derived drugs were consecutively co-administered at the standard clinical doses, WBC was markedly decreased with significant differences compared with each drug alone. One reason for these effects is likely to be the significant elevation of the 5-FU blood concentration compared with each drug alone. This hypothesis was also supported by the increase 
in the AUC after a single co-administration of BOF-A2 with 5-FU or UFT.

Furthermore, BV-araU has been developed as an antiviral drug (18), and severe leukopenia has been induced by its co-administration with 5-FU-derived anticancer drugs. It was thought that the mechanism behind this phenomenon was the inhibitory activity of BVU, which is a metabolite of BV-araU $(18,19)$, upon 5-FU degradation. After co-administration of UFT ( 10 or $20 \mathrm{mg} / \mathrm{kg}$ ) and $\mathrm{BV}$-araU $(20 \mathrm{mg} / \mathrm{kg})$, there was a marked decrease in peripheral WBC, accompanied by an elevated plasma 5FU concentration. This phenomenon is considered to be based on two mechanisms: the persistence of BVU in the blood and the irreversible inhibition of 5-FU catabolism by BVU, even though its inhibitory activity is only onesixth that of uracil $(14,19,20)$. However, co-administration of BOF-A2 $(10,20$ or $40 \mathrm{mg} / \mathrm{kg})$ with BV-araU $(20$ $\mathrm{mg} / \mathrm{kg}$ ) did not decrease peripheral WBC. This finding was attributable to the fact that the inhibitory potency of CNDP for the degradation of 5-FU is 6000 times greater than that of BVU. As a result, the co-administration of BV-araU did not additionally inhibit 5-FU degradation.

Thus, although leukopenia was increased and the blood 5-FU concentration was elevated after co-administration of BOF-A2 with other 5-FU-derived drugs, none of the marked changes caused by the co-administration of UFT with BV-araU were seen after the co-administration of BOF-A2 with BV-araU.

\section{REFERENCES}

1 Fujii S, Kitano S, Ikenaka $\mathrm{K}$ and Shirasaka T: Effect of coadministration of clinical doses of 1-(2-tetrahydrofuryl)-5fluorouracil and level of 5 -fluorouracil in rodents. Gann 70, 209-214 (1979)

2 Spector T, Harrington JA and Porter DJT: 5-Ethynyluracil (776C85): Inactivation of dihydropyrimidine dehydrogenase in vivo. Biochem Pharmacol 46, 2243-2248 (1993)

3 Naguib FNM, Hao SN and Kouni MH: Potentiation of 5fluorouracil efficacy by the dihydrouracil dehydrogenase inhibitor 5-benzoyloxybenzyl uracil. Cancer Res 54, 5166-5170 (1994)

4 Porter DJT, Chestnut WG, Taylor LCE, Merrill BM and Spector T: Inactivation of dihydropyrimidine dehydrogenase by 5-iodouracil. J Biol Chem 266, 19988 - 19994 (1994)

5 Tatsumi K, Yamauchi T, Kiyono K, Kishi K, Yanagihara $Y$, Imaoka $T$, Kawaguchi $T$ and Kubo $M$ : 3-Cyano-2,6-dihydroxypyridine (CNDP), a new potent inhibitor of dihydrouracil dehydrogenase. J Biochem 114, $912-918$ (1993)

6 Hirohashi M, Kido M, Yamamoto Y, Kojima Y, Jitukawa K and Fujii S: Synthesis of 5-fluorouracil derivatives containing an inhibitor of 5-fluorouracil degradation. Chem Pharm Bull (Tokyo) 41, 1498-1506 (1993)
7 Fujii S, Fukushima M, Shimamoto Y, Oshimo H, Imaoka T and Shirasaka T: Antitumor activity of BOF-A2, a new 5fluorouracil derivative. Jpn J Cancer Res 80, 173-181 (1989)

8 Miyauchi S, Imaoka T, Utsunomiya T, Hayashi K, Kubo M, Kawaguchi $\mathrm{T}$ and Matsui $\mathrm{Y}$ : Oral administration of BOF-A2 to rats with lung transplanted tumors results in increased 5 fluorouracil levels. Jpn J Cancer Res 85, 665-668 (1994)

9 Nakai Y, Furuse K, Ohta M, Yamaguchi Y, Fujii M, Asakawa $M$, Fukuoka $M$, Yoshida $K$ and Niitani $H$ : Efficacy of a new 5fluorouracil derivative, BOF-A2, in advanced non-small cell cancer. A multicenter phase II study. Acta Oncol 33, 523-526 (1994)

10 David S: Deaths bring clinical trials under scrutiny in Japan. Nature 369, 697 (1994)

11 Fujii S, Shimamoto Y, Ohshimo H, Imaoka T, Motoyama M, Fukushima $M$ and Shirasaka T: Effects of the plasma concentration of 5-fluorouracil and the duration of continous yenous infusion of 5-fluorouracil with an inhibitor of 5-fluorouracil degradation on Yoshida sarcoma in rats. Jpn J Cancer Res 80, $167-172$ (1989)

12 Moure MA, Stolfi RL and Martin DS: Hematologic effects of interleukin-1 beta, granulocyte colony-stimulating factor, and granulocyte macrophage colony-stimulating factor in tumorbearing mice treated with fluorouracil. J Natl Cancer Inst 82, 1031 - 1037(1990)

13 Stolhi RL, Sawyer RC, Nayak R, Spiegelman S and Martin DS: Protection by testosterone from fluorouracil-induced toxicity without loss of anticancer activity against autochthonaus murine breast tumors. Cancer Res 40, 2730-2735 (1980)

14 Desgranges C, Razaka G, Clercq ED, Herdewijn P, Balzarini J, Drouillet $\mathrm{F}$ and Bricaud $\mathrm{H}$ : Effect of (E)-5-(2-bromovinyl) uracil on the catabolism and antitumor activity of 5-flurorouracil in rats and leukemic mice. Cancer Res 46, 1094-1101 (1986)

15 Kubo M, Sasabe $H$ and Shimizu T: Highly sensitive method for the determination of 5-fluorouracil in biological samples in the presence of 2 -deoxy-5-fluorouridine by gas chromatographymass spectrometer. J Chromatogr 564, $137-145$ (1991)

16 Okayasu $T$, Sugiyama $T$ and Miyauchi $S$ : Inhibition of catabolic pathway of 5-fluorouracil by 3-cyano-2,6-dihydroxypyridine in human lung cancer tissue. Jpn J Cancer Res 85, $101-105$ (1994)

17 Naguib FNM, Kouni MHK and Cha S: Enzymes of uracil catabolism in normal and neoplastic human tissues. Cancer Res 45, 5405-5412 (1985)

18 Ijichi $\mathrm{K}$, Ashida $\mathrm{N}$ and Machida $\mathrm{H}$ : Effect of 1- $-\mathrm{D}-\mathrm{D}$ arabinofuranosyl $(E)$-5(2-bromovinyl)uracil against herpes virus type 1 infection in immunosuppressed mice. Antimicrob Agents Chemother 34, 2431-2433(1990)

19 Desgranges C, Razaka G, Drouillet F, Bricaud H, Herdewijn P and Clercq ED: Regulation of the antiviral drug $(E)-5$-(2bromovinyl)-2'-deoxyuridine in vivo. Nucleic Acids Res 12, $2081-2090$ (1984)

20 Ashida N, Ijichi K, Watanabe $\mathrm{Y}$ and Machida $\mathrm{H}$ : Metabolism of 5 -ether prodrugs of 1-j-D-arabinofuranosyol-E-5-(2bromovinyl)uracil in rats. Biochem Pharmacol 46, 2201-2207 (1993) 